\title{
IMPLEMENTASI METODE SIMPLE ADDITIVE WEIGHTING PADA SISTEM PENDUKUNG KEPUTUSAN PERPANJANGAN MASA KERJA KARYAWAN KONTRAK
}

\author{
Putri Taqwa Prasetyaningrum, Ari Wibowo \\ Program Studi Sistem Informasi, Fakultas Teknologi Informasi, Universitas Mercu Buana Yogyakarta \\ Jl. Wates Km. 10 Yogyakarta, Indonesia \\ putriemercubuana-yogya.ac.id
}

\begin{abstract}
Employee performance in the company is always assessed for the continuity and development of the company for the better by the support from potential human resources, discipline, good teamwork, and honesty. That is what is expected of a company, such as the Jogjakarta Indoluxe Hotel. For the continuity of the company's operations and the to ability compete with other hotels, the Indoluxe Hotel Jogjakarta also applies a contract employee work system. Since it still applies a manual system, determining the length of the period of an employment contract is limited to knowing and evaluating directly from the employee. The new system is expected to be able to determine employees who truly excel for the company. In this case, there needs to be a follow up to find out the results. This is by knowing the existing employee data, such as through absenteeism, teamwork, and loyalty in their work. This is done by taking some employee data as a source in this decision support system. Those employees' data can lead to the results can be obtained accordingly, because every employee has different data. Therefore after analysis, it is clean which employees are disciplined and which are not. To obtain valid employee data, it is expected that a decision support system in the extension of the work period of the contract is implemented.
\end{abstract}

Keywords: Contract Employee, Decision Support Systems. Simple Additive Weighting

\begin{abstract}
Abstrak - Kinerja karyawan dalam perusahaan selalu dinilai untuk kelangsungan dan perkembangan perusahaan tersebut menjadi lebih baik. Dengan didukung adanya sumber daya manusia yang berpotensial, disiplin, kerja tim yang bagus dan kejujuran. Hal itulah yang diharapakan suatu perusahaan, seperti Hotel Indoluxe Jogjakarta. Untuk kelangsungan operasional perusahaan dan mampu bersaing dengan hotel lainnya, maka Hotel Indoluxe Jogjakarta pun menerapkan sistem kerja karyawan kontrak. Karena masih menggunakan sistem manual, penentuan masa kerja karyawan kontrak sebatas tahu dan menilai langsung dari karyawan tersebut. Dengan adanya sistem baru diharapkan dapat menentukan karyawan yang benar-benar berprestasi untuk perusahaan.Dalam hal ini perlu adanya tindak lanjut untuk mengetahui hasilnya. Yaitu mengetahui data karyawan yang ada, seperti absensi, kerja tim dan loyalitas dalam kerjanya. Dengan mengambil beberapa data karyawan sebagai sumber dalam sistem pendukung keputusan ini.Dengan adanya data dari karyawan, bisa diperoleh hasil yang sesuai, Karena antara karyawan satu dengan karyawan lainnya mempunyai data yang berbeda-beda. Sehingga setelah dilakukan analisa, terlihat karyawan mana yang disiplin waktunya dengan yang tidak.Jadi untuk mendapatkan hasil data karyawan yang valid, diharapkan menerapkan sistem pendukung keputusan dalam perpanjangan masa kerja karyawan kontrak.
\end{abstract}

Kata kunci: Karyawan Kontrak, Sistem Pendukung Keputusan, Simple Additive Weighting.

\section{PENDAHULUAN}

Indoluxe Jogjakarta adalah perusahaan yang bergerak dibidang perhotelan, yang ditunjang dengan lengkapnya fasilitas dan sumber daya manusia yang terpercaya. Untuk meningkatkan kinerja dan produktifitas secara maksimal, maka perusahaan dapat memberlakukan penilaian terhadap kinerja tenaga kerja, dan menerapkan sistem tenaga kerja kontrak. Dalam perpanjangan tenaga kerja kontrak merupakan agenda yang dilaksanakan oleh perusahaan dimana tenaga kerja yang memiliki kinerja yang baik bagi perusahaan berhak mendapat kontrak untuk masa waktu kedepan.
Perpanjangan tenaga kerja kontrak dilakukan dalam suatu periode tertentu, dan hanya tenaga kerja yang memiliki potensi atau prestasi yang berhak mendapatkan kesempatan untuk mendapat kontrak selanjutnya. Sehingga perusahaan juga mendapatkan sumber daya manusia yang terbaik. Sebagian besar sistem pendukung keputusan yang digunakan diperusahaan masih bersifat manual. Hal ini membuat manajer atau pemilik perusahaan masih kesulitan untuk menentukan perpanjangan kontrak kerja karyawan setiap periodenya. Apabila dikembangkan dengan benar, sistem pengambilan perpanjangan masa kerja karyawan kontrak ini sangat membantu dalam pengambilan keputusan. Dengan sistem pendukung keputuisan ini membantu pimpinan 
perusahaan dalam memtuskan pelamar mana yang akan dipilih[1]. Seperti pada penelitian Wayan yang merealisasikan sistem pendukung keputusan ini, untuk penerimaaan karyawan[2]. Membangun suatu sistem pendukung keputusan yang dapat membantu perusahaan dalam memberikan untuk menilai dan memilih calon karyawan yang layak atau tidak untuk diterima menjadi seorang karayawan pada perusahaan tersebut[3]. Metode SAW adalah sebuah teknik yang dibenarkan untuk menentukan nilai terbaik dari beberapa kriteria yang telah ditentukan, oleh karena itu metode ini sangat cocok digunakan untuk menentukan karyawan yang akan diterima oleh PT. Karya Sahata,sehingga karyawan yang akan diterima diambil dari nilai yang tertinggi[4]. Dengan menggunakan metode Simple Additive Weighting (SAW) dapat memberikan rekomendasi. Nilai dengan ranking tertinggi merupakan daerah yang dapat rekomendasikan untuk dibuka cabang baru[5]. Pada penelitian Harryanto dengan menggunakan metode SAW akan terlihat perbedaannya pada saat proses perangkingan saat menentukan guru PNS berprestasi[6]. Salah satu contohnya yang dibahas disini adalah kasus mencari seleksi atlet silat sekotawaringin timur dari 1 sampai 100 orang ini akan dites dan dinilai dari alternatif yang ditentukan, sampai pada akhirnya mencari dan menemukan mana juara 1 dari 100 orang tersebut yang mendapatkan rengking yang terbaik[7]. Keberadaan SPK pada perusahaan atau organisasi bukan untuk menggantikan tugas-tugas pengambil keputusan, tetapi merupakan sarana yang membantu bagi mereka dalam pengambilan keputusan. Dengan menggunakan datadata yang diolah menjadi informasi untuk mengambil keputusan dari masalah-masalah semi-terstruktur. Dalam implementasi SPK, hasil dari keputusankeputusan dari sistem bukanlah hal yang menjadi patokan, pengambilan keputusan tetap berada pada pengambil keputusan. Sistem hanya menghasilkan keluaran yang mengkalkulasi data-data sebagaimana pertimbangan seorang pengambil keputusan. Sehingga kerja pengambil keputusan dalam mempertimbangkan keputusan dapat dimudahkan[8].

Sistem yang akan dibuat ini disharapkan dapat menjadi tools dalam perpanjangan masa kerja karyawan kontrak di Indoluxe Hotel Jogjakarta.

\section{A. Karyawan}

Karyawan adalah seseorang yang memiliki keterampilan dan kemampuan yang ditawarkan kepada perusahaan. Agar perusahaan tersebut dapat melaksanakan visi dan misi serta meraih keuntungan. Dan bagi seseorang tersebut mengharapkan upah atau gaji yang sesuai dengan keterampilan yang dimilikinya.

\section{B. Karyawan Kontrak}

Dalam istilah hukum pekerja kontrak sering disebut "pekerja PKWT", maksudnya pekerja dengan Perjanjian Kerja Waktu Tertentu. Hal ini dikarenakan yang dinamakan pekerja kontrak itu bekerja menggunakan sistem PKWT (Perjanjian Kerja Waktu Tertentu). Dasar hukum dari pekerja kontrak atau pekerja dengan Perjanjian Kerja Waktu Tertentu diatur dalam Pasal 56, 57, 58, dan 59 Undang-Undang Ketenagakerjaan.

Pada Pasal 56 ayat (1) Undang-Undang "Ketenagakerjaan mengatur perjanjian kerja dibagi menjadi dua jenis, yaitu perjanjian kerja waktu tertentu dan perjanjian kerja untuk waktu tidak tertentu. Perjanjian kontrak kerja untuk pekerja PKWT memang dapat diperpanjang atau diperbaharui. Akan tetapi, terdapat batasan waktunya".

\section{Sistem Penunjang Keputusan}

Sistem pendukung keputusan ialah proses pengambilan keputusan dibantu menggunakan komputer untuk membantu pengambil keputusan dengan menggunakan beberapa data dan model tertentu untuk menyelesaikan beberapa masalah yang tidak terstruktur[9]. Sistem pendukung keputusan adalah sistem informasi interaktif yangmenyediakan informasi, pemodelan dan manipulasi data yang digunakan untukmembantu mengambil keputusan pada situasi semi terstruktur dan tak seorangpuntahu secara pasti bagaimana keputusan seharusnya dibuat[10].

\section{METODE PENELITIAN}

\section{A. Bahan Penelitian}

1. Jurnal dan buku yang membahas mengenai masa perpanjangan karyawan kontrak, Sistem Pendukung Keputusan, dan metode Simple Additive Weighting (SAW).

2. Data wawancara Manajer Indoluxe Hotel Jogjakarta mengenai kriteria dalam perpanjangan karyawan kontrak

\section{B. Alat Penelitian \\ 1. Perangkat Lunak (Software)}

Tabel 1. Perangkat Lunak

\begin{tabular}{|l|l|l|}
\hline No & Jenis & Perangkat Lunak \\
\hline 1 & Processor & Intel Core i 3 \\
\hline 2 & RAM & DDR3 4GB \\
\hline 3 & Harddisk & 320GB \\
\hline 4 & Graphic & NVidia GeForce 9300 \\
\hline
\end{tabular}


2. Perangkat Keras (Hardware)

Tabel 2. Perangkat Keras

\begin{tabular}{|l|l|l|}
\hline NO & Jenis & Perangkat Lunak \\
\hline 1 & Sistem Operasi & Microsoft Windows 10 \\
\hline 2 & Programming & $\begin{array}{l}\text { Adobe Dreamweaver CS 5, } \\
\text { Notepad++ }\end{array}$ \\
\hline 3 & Dokumentasi & Microsoft Office 2013 \\
\hline 4 & Desain & $\begin{array}{l}\text { Dia, Pencil, Adobe } \\
\text { Photoshop CS 3 }\end{array}$ \\
\hline 5 & $\begin{array}{l}\text { Pengujian dan } \\
\text { Punning } \\
\text { Program }\end{array}$ & $\begin{array}{l}\text { XAMPP Server, Google } \\
\text { Chrome }\end{array}$ \\
\hline
\end{tabular}

\section{Jalan Penelitian}

1. Intelegensi

a. Wawancara

Wawancara ini dilakukan untuk mendapatkan data yang berhubungan dengan perpanjangan masa kerja karyawan kontrak untuk mengetahui kriteria serta bobot masing-masing kriteria dalam perpanjangan karyawan kontrak .

b. Studi Kepustakaan.

Studi kepustakaan ini berawal dari teknik pengumpulan data dengan melakukan pemilihan dari berbagai jurnal, buku, internet, catatan dan dari sumber lainya, serta berbagai yang berkaitan dengan masalah yang ingin dipecahkan

2. Desain

Dari masalah yang diuraikan dalam tahap intelegensi, maka dibutuhkan sebuah sistem yang dapat membantu menentukan perpanjangan masa kerja karyawan kontrak disuatu perusahaan.

3. Pemilihan.

Metode SAW sering dikenal istilah metode penjumlahan terbobot. Seperti dibawah ini:

$$
r_{i j}=\left\{\begin{array}{l}
\frac{\left\{X_{i j}\right.}{\operatorname{Maxx}_{i j}} \\
\frac{\left\{\operatorname{Min} x_{i j}\right.}{X_{i j}}
\end{array}\right.
$$

Keterangan:

$\mathrm{r}_{\mathrm{ij}}=$ nilai rating kinerja ternormalisasi

$\mathrm{X}_{\mathrm{ij}} \quad=$ nilai atribut yang dimiliki dari setiap atribut

$\operatorname{Maxx}_{\mathrm{ij}}=$ nilai terbesar dari setiap kinerja

$\operatorname{Minx}_{\mathrm{ij}}=$ nilai terkecil dari setiap kriteria

Benefit $=$ jika nilai terbesar adalah terbaik

Cost $=$ jika nilai terkecil adalah terbaik

Dimana rij adalah rating kinerja ternormalisasi dari alternatif $A i$ pada atribut $\mathrm{C} j$;

$\mathrm{i}=1,2,3, \ldots, \mathrm{m}$ dan $\mathrm{j}=1,2,3, \ldots, \mathrm{n}$

Nilai prefensi untuk setiap alternatif $(\mathrm{V} i)$

$\mathrm{V}_{\mathrm{i}}=\sum^{\mathrm{n}} \mathrm{w}_{\mathrm{j}} \mathrm{r}_{\mathrm{ij}}$

$$
\mathrm{j}=1
$$

Nilai Vi yang lebih besar mengindekasi bahwa Ai lebih terpilih

Keterangan :

$\mathrm{Vi} \quad=$ rangking untuk setiap alternatif

$\mathrm{Wj} \quad=$ nilai bobot dari setiap kinerja

$\mathrm{Rij}=$ nilai rating kinerja ternormalisasi

4. Implementasi

a. Use Case Diagram Karyawan Kontrak

Use case Diagram data Karyawan dari sistem pendukung keputusan perpanjangan karyawan kontrak dapat dilihat pada Gambar 1.

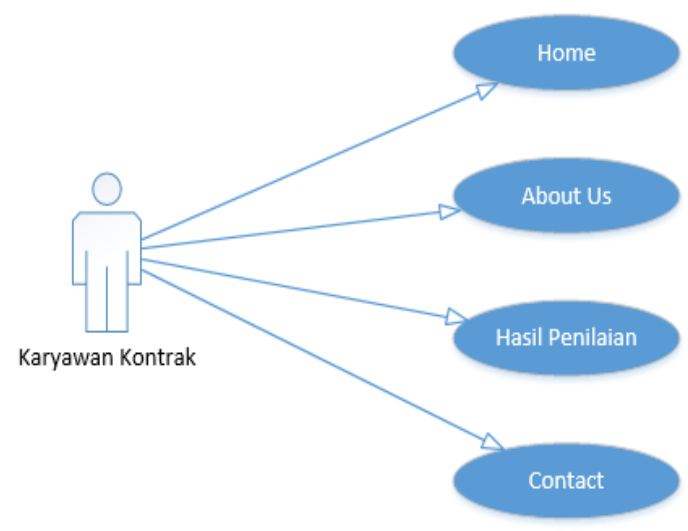

Gambar 1. Use Case Diagram Karyawan Kontrak

b. Use Case Diagram Admin

Use Case Diagram Admin sistem pendukung keputusan Perpanjangan karyawan kontrak dapat dilihat pada Gambar 2.

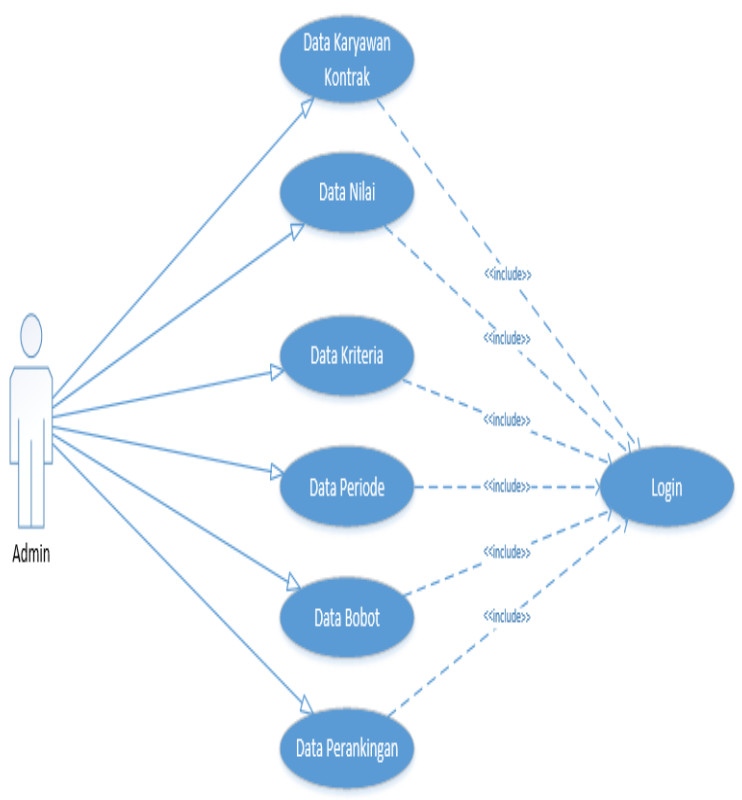

Gambar 2. Use Case Diagram Admin 
c. Flow Chart System

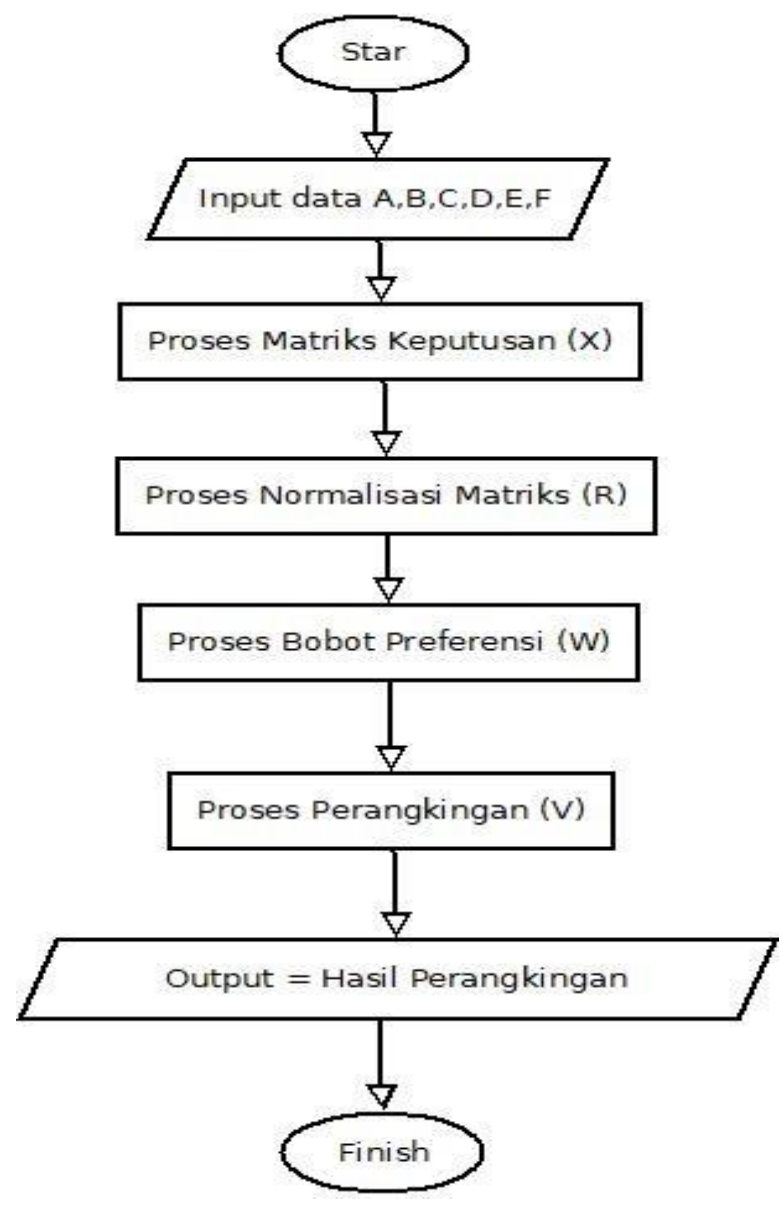

Gambar 3. Flow Chart System

d. Database.

1. Tabel User

Struktur Tabel user dapat dilihat pada Tabel 3.

Tabel 3. Tabel User

\begin{tabular}{|l|l|l|l|}
\hline Field & Type & Nilai & Keterangan \\
\hline Id_user & Int & 10 & Primary_Key \\
\hline $\begin{array}{l}\text { Nama_le } \\
\text { ngkap }\end{array}$ & Varchar & 50 & \\
\hline $\begin{array}{l}\text { Passwor } \\
\text { d }\end{array}$ & Varchar & 50 & \\
\hline
\end{tabular}

2. Tabel Karyawan Kontrak

Tabel Karyawan Kontrak digunakan untuk menyimpan data Karyawan Kontrak. Struktur Tabel Karyawan Kontrak dapat dilihat pada Tabel 4.
Tabel 4. Tabel Karyawan Kontrak

\begin{tabular}{|l|l|l|l|}
\hline Field & Type & Nilai & $\begin{array}{l}\text { Keterang } \\
\text { an }\end{array}$ \\
\hline $\begin{array}{l}\text { Id_Karyawan_Kont } \\
\text { rak }\end{array}$ & Int & 10 & $\begin{array}{l}\text { Primary_ } \\
\text { Key }\end{array}$ \\
\hline Nama & Varchar & 50 & \\
\hline Jenis_kelamin & Emun & $\begin{array}{l}\text { (Laki- } \\
\text { laki,P } \\
\text { eremp } \\
\text { uan) }\end{array}$ & \\
\hline Alamat & Varchar & 50 & \\
\hline Id_periode & Int & 10 & \\
\hline No_hp & Varchar & 12 & \\
\hline Foto & Varchar & 100 & \\
\hline
\end{tabular}

a. Relasi Tabel

Gambar dari database yang sudah terelasi, dan dapat dilihat pada Gambar 4.

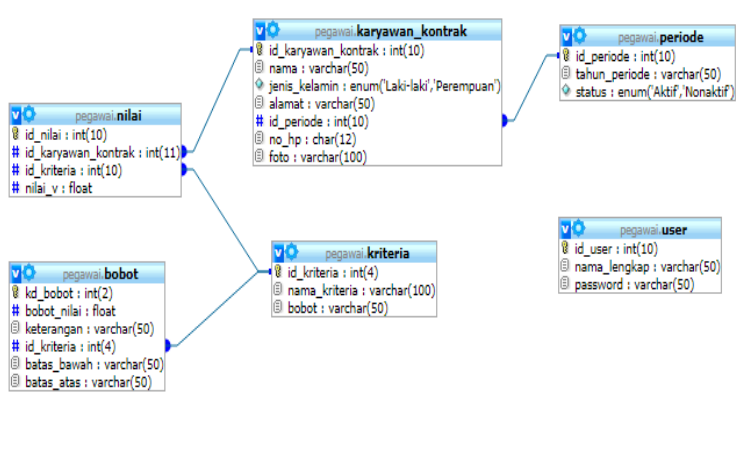

Gambar.4. Relasi Tabel

b. Rancangan Halaman Level Karyawan Kontrak

Rancangan halaman level Karyawan Kontrak dapat dilihat pada Gambar 5.

Sistem Penjunjang keputusan Perpanjangan Masa Kerja Karyawan

Home

Selamat Datang

@Skripsi Sistem Penunjang Keputusan

Gambar 5. Rancangan Halaman Level Karyawan Kontrak

c. Rancangan Level Admin

Sebelum mengakses halaman level admin, pengguna diharuskan untuk login terlebih dahulu dengan lebih dahulu memasukkan calon username dan 
password. Rancangan halaman login dapat dilihat pada Gambar6.

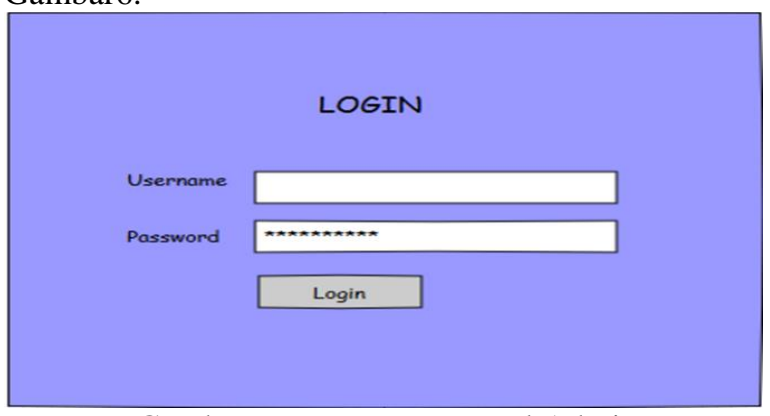

Gambar 6. Rancangan Level Admin

\section{HASIL DAN PEMBAHASAN}

\section{A. Hasil Penelitian}

Penelitian dan aplikasi sistem pendukung keputusan perpanjangan karyawan kontrak ini dibuat sebagai media untuk membantu bagian HRD di perusahaan untuk menentukan karyawan kontrak yang akan diperpanjang atau tidak.

Berdasarkan penggunanya, sistem ini dikembangkan menjadi 2 bagian. Bagian pertama yaitu antarmuka untuk level karyawan kontrak, yakni antarmuka yang akan digunakan oleh karyawan kontrak untuk melihat informasi-informasi.

\section{B. Antarmuka Level Karyawan Kontrak}

1. Tampilan Halaman Home Halaman Home dapat dilihat pada Gambar 7.
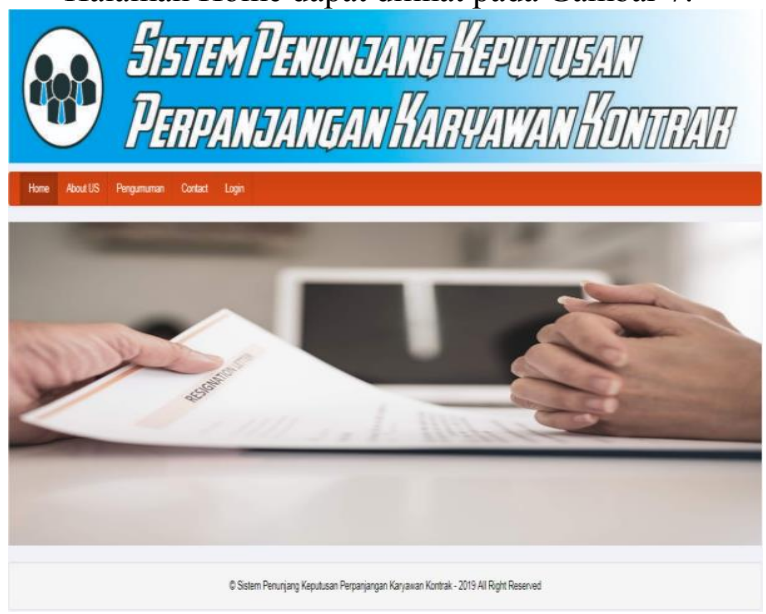

Gambar 7. Halaman Utama Sistem
2. Tampilan Halaman Contact Halaman Contact dapat dilihat pada Gambar 8.

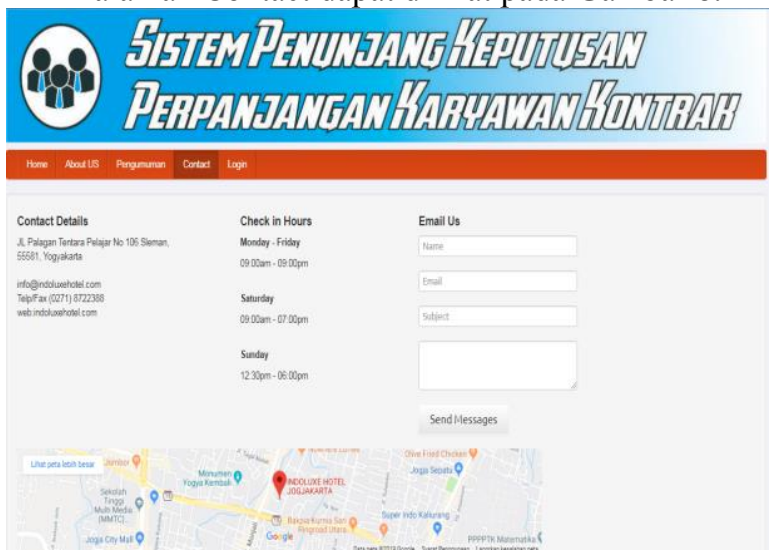

Gambar 8. Halaman Utama Contact

3. Tampilan Halaman Pengumuman Halaman Pengumuman dapat dilihat pada Gambar 9.

DATA NILAI PERANGKINGAN

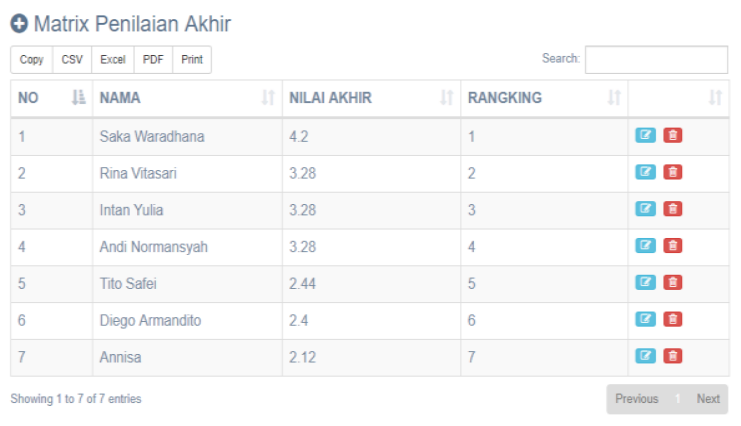

Gambar 9. Halaman Pengumuman

4. Tampilan Halaman Data Karyawan kontrak

Pada halaman Data karyawan kontrak, admin dapat melakukan tambah data karyawan kontrak, edit data karyawan kontrak, hapus data karyawan kontrak. Selain itu pada halaman data karyawan kontrak, admin juga dapat melakukan detail karyawan kontrak, tambah nilai karyawan kontrak, edit nilai karyawan kontrak dan hapus nilai karyawan kontrak. Tampilan halaman data karyawan kontrak dapat dilihat pada Gambar 10.
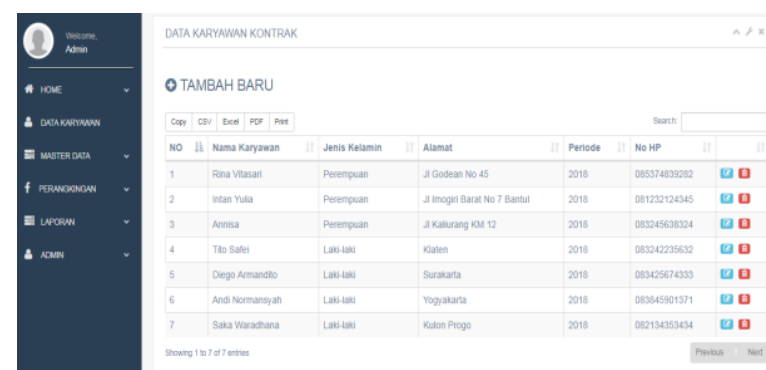

Gambar 10.Halaman Data Karyawan Kontrak 
5. Halaman Data Kriteria

Tampilan halaman data Kriteria dapat dilihat pada Gambar 11.

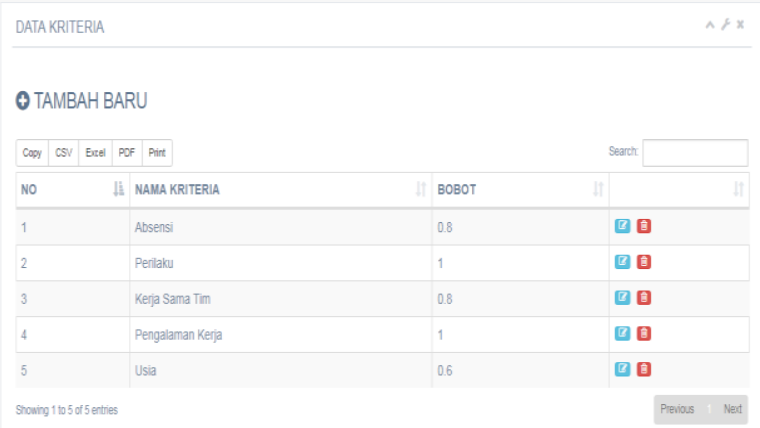

Gambar 11. Halaman Data Kriteria

6. Tampilan Halaman Data Bobot

Tampilan halaman data Bobot dapat dilihat pada Gambar 11.

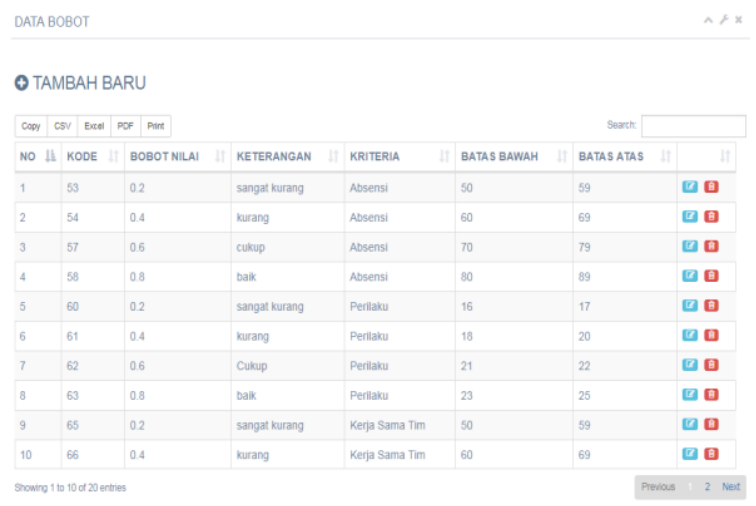

Gambar 11. Halaman Data Bobot

\section{Tampilan Halaman Perangkingan}

Tampilan halaman perangkingan dapat dilihat pada Gambar 12 s/d Gambar 16.

Nilai awal setiap alternatif pada setiap kriteria dapat dilihat pada Gambar 12

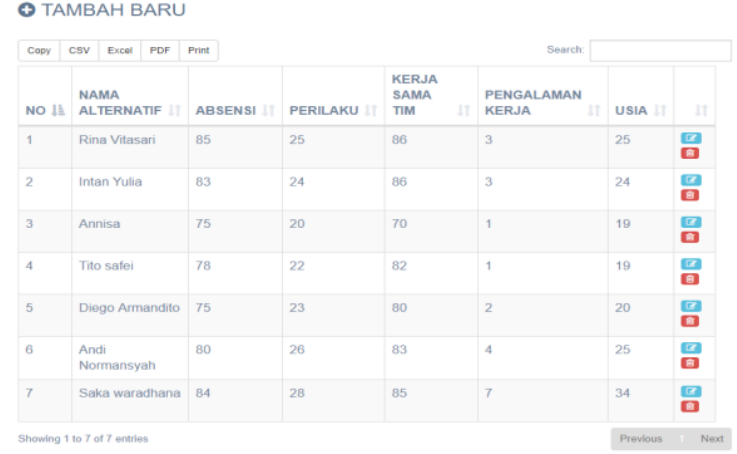

Gambar 12. Nilai Awal
Matriks keputusan (X) dapat dilihat pada Gambar 13.

DRTANLA IMTR:

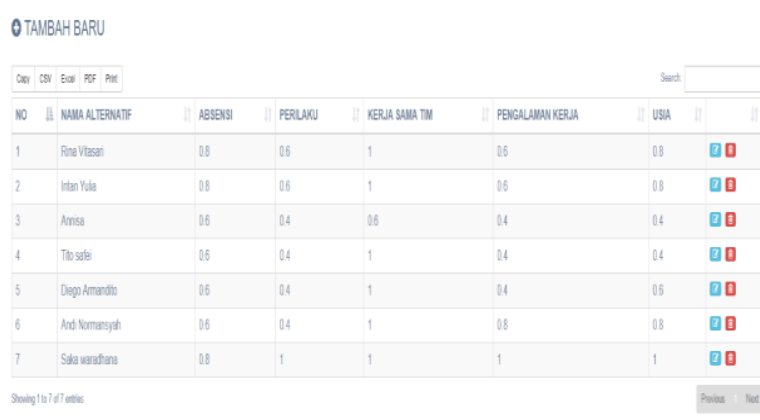

Gambar 13. Matriks Keputusan (X)

Matriks ternormalisasi (R) dapat dilihat pada Gambar 14.

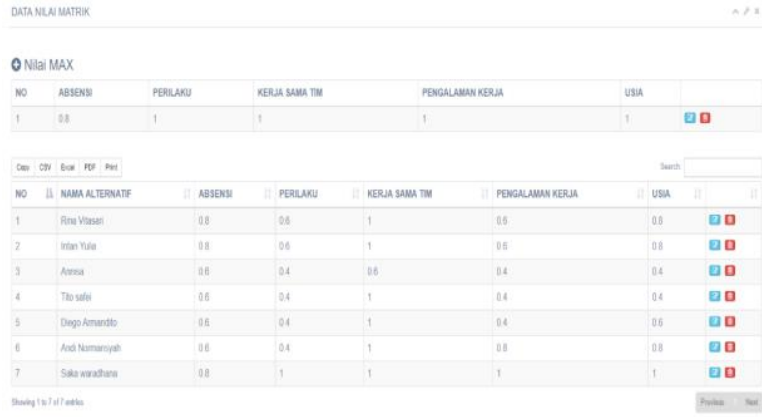

Gambar 14. Matriks Ternormalisasi (R)

Matriks Bobot Preferensi (W) dapat dilihat pada Gambar 15.

DATA NILAI MATRIK

\section{O Matrix Bobot Preferensi}

\begin{tabular}{|l|l|l|l|l|l|l|}
\hline NO & ABSENSI & PERILAKU & KERJA SAMA TIM & PENGALAMAN KERJA & USIA & \\
\hline 1 & 0.8 & 1 & 0.8 & 1 & 0.6 & [ $\mathbf{0}$ \\
\hline
\end{tabular}

Gambar 15. Matriks Bobot Preferensi (W)

Matriks perangkingan (V) dapat dilihat pada gambar 20 .

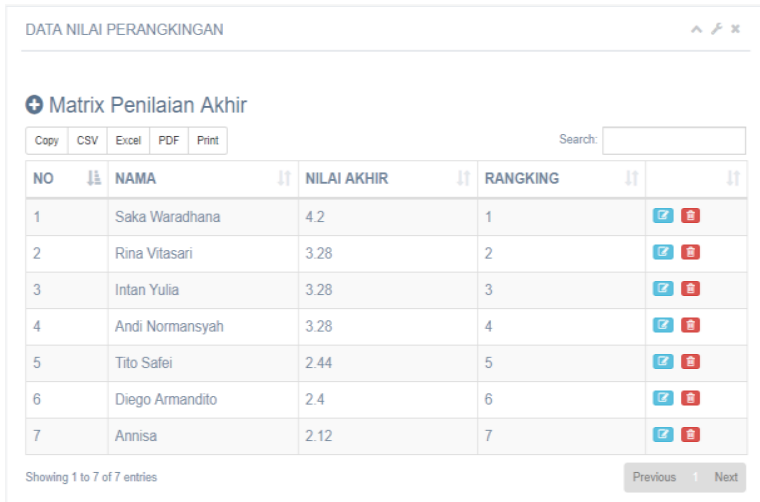

Gambar 16. Matriks Perangkingan (V) 


\section{Analisis dan Pembahasan Metode SAW}

Sebelum masuk dalam proses perhitungan SAW langkah pertama yaitu menentukan bobot kepentingan untuk setiap kriteria. Bobot kriteria di dapat melalui hasil wawancara dengan manajer Raminten Uborampe yang digunakan sebagai acauan untuk pengambilan keputusan rekrutmen pegawai, dapat dilihat pada Tabel 3.

Tabel 3. Bobot Kriteria

\begin{tabular}{|c|c|c|c|c|}
\hline Kode & Kriteria & Bobot & Nilai & $\begin{array}{c}\text { Keterang } \\
\text { an }\end{array}$ \\
\hline C1 & Absensi & Penting & 0.8 & Benefit \\
\hline C2 & Perilaku & $\begin{array}{c}\text { Sangat } \\
\text { Penting }\end{array}$ & 1 & Benefit \\
\hline C3 & $\begin{array}{c}\text { Kerja Sama } \\
\text { Tim }\end{array}$ & Penting & 0.8 & Benefit \\
\hline C4 & $\begin{array}{c}\text { Pengalaman } \\
\text { Kerja }\end{array}$ & $\begin{array}{c}\text { Sangat } \\
\text { Penting }\end{array}$ & 1 & Benefit \\
\hline C5 & Usia & Cukup & 0.6 & Benefit \\
\hline
\end{tabular}

Bobot W yaitu bobot dari masing-masing kriteria.

Bobot $\mathrm{W}=[0.8,1,0.8,1,0.6]$

Berikut merupakan Data Karyawan kontrak baru. Dapat dilihat pada Tabel 4.

Tabel 4. Data Karyawan Kontrak

\begin{tabular}{|l|c|c|c|c|c|}
\hline \multirow{2}{*}{ Nama } & \multicolumn{4}{|c|}{ Kriteria } & \\
\cline { 2 - 6 } & Absensi & Perilaku & $\begin{array}{c}\text { Kerja } \\
\text { sama } \\
\text { Tim }\end{array}$ & $\begin{array}{c}\text { Peng } \\
\text { alam } \\
\text { an } \\
\text { Kerja }\end{array}$ & Usia \\
\hline $\begin{array}{l}\text { Rina } \\
\text { Vitasari }\end{array}$ & 85 & 22 & 86 & 3 & 25 \\
\hline Intan Yulia & 83 & 22 & 86 & 3 & 24 \\
\hline Annisa & 75 & 22 & 70 & 1 & 19 \\
\hline Tito Safe'i & 78 & 23 & 82 & 1 & 19 \\
\hline $\begin{array}{l}\text { Diego } \\
\text { Armandito }\end{array}$ & 75 & 23 & 80 & 2 & 20 \\
\hline $\begin{array}{l}\text { Andi } \\
\text { Normansya } \\
\text { h }\end{array}$ & 80 & 24 & 83 & 4 & 25 \\
\hline $\begin{array}{l}\text { Saka } \\
\text { Waradhana }\end{array}$ & 84 & 22 & 85 & 7 & 34 \\
\hline
\end{tabular}

Langkah selanjutnya adalah pembentukan matriks keputusan. Dapat dilihat pada Tabel 5.

Tabel 5. Matriks Keputusan

\begin{tabular}{|c|c|c|c|c|c|}
\hline \multirow{2}{*}{$\begin{array}{c}\text { Altern } \\
\text { atif }\end{array}$} & \multicolumn{4}{|c|}{ Kriteria } & \multirow[b]{2}{*}{$\mathrm{C} 5$} \\
\hline & $\mathrm{C} 1$ & $\mathrm{C} 2$ & C3 & $\mathrm{C} 4$ & \\
\hline A1 & 0.8 & 0.6 & 1 & 0.6 & 0.8 \\
\hline $\mathrm{A} 2$ & 0.8 & 0.6 & 1 & 0.6 & 0.8 \\
\hline A3 & 0.6 & 0.4 & 0.6 & 0.4 & 0.4 \\
\hline A4 & 0.6 & 0.4 & 1 & 0.4 & 0.4 \\
\hline A5 & 0.6 & 0.4 & 0.8 & 0.4 & 0.6 \\
\hline A6 & 0.6 & 0.6 & 1 & 0.8 & 0.8 \\
\hline A7 & 0.8 & 1 & 1 & 1 & 1 \\
\hline
\end{tabular}

Sehingga diperoleh hasil normalisasi matriks (X) dapat dilihat pada Tabel 6

Tabel 6. Normalisasi Matriks

\begin{tabular}{|l|l|l|l|l|l|l|}
\hline \multirow{2}{*}{$\begin{array}{c}\text { N } \\
\text { o }\end{array}$} & \multirow{2}{*}{$\begin{array}{c}\text { Alterna } \\
\text { tif }\end{array}$} & \multicolumn{5}{|c|}{ Kriteria } \\
\cline { 3 - 7 } & & $\mathrm{C} 1$ & $\mathrm{C} 2$ & $\mathrm{C} 3$ & $\mathrm{C} 4$ & $\mathrm{C} 5$ \\
\hline 1 & $\mathrm{~A} 1$ & 1 & 0.6 & 1 & 0.6 & 0.8 \\
\hline 2 & $\mathrm{~A} 2$ & 1 & 0.6 & 1 & 0.6 & 0.8 \\
\hline 3 & $\mathrm{~A} 3$ & 0.75 & 0.4 & 0.6 & 0.4 & 0.4 \\
\hline 4 & $\mathrm{~A} 4$ & 0.75 & 0.4 & 1 & 0.4 & 0.4 \\
\hline 5 & $\mathrm{~A} 5$ & 0.75 & 0.4 & 0.8 & 0.4 & 0.6 \\
\hline 6 & A6 & 0.75 & 0.6 & 1 & 0.8 & 0.8 \\
\hline 7 & A7 & 1 & 1 & 1 & 1 & 1 \\
\hline
\end{tabular}

Langkah selanjutnya yaitu Perangkingan (V), proses perangkingan diperoleh dari perkalian matriks ternormalisasi (R) dengan vector bobot (W) menggunakan persamaan di bawah ini:

Menghasilkan hasil perhitungan sebagai berikut :

$\mathrm{V} 1=(1)(0.8)+(0.6)(1)+(1)(0.8)+(0.6)(1)+(0.8)(0.6)$

$=0.8+0.6+0.8+0.6+0.48=3.28$

$\mathrm{V} 2=(1)(0.8)+(0.6)(1)+(1)(0.8)+(0.6)(1)+(0.8)(0.6)$

$=0.8+0.6+0.8+0.6+0.48=3.28$

$\mathrm{V} 3=(0.75)(0.8)+(0.4)(1)+(0.6)(0.8)+(0.4)(1)+$

$(0.4)(0.6)$

$=0.6+0.4+0.48+0.4+0.24=2.12$

Sehingga hasil perangkingan dapat dilihat pada Tabel 7

Tabel 7.Hasil Perangkingan

\begin{tabular}{|l|l|}
\hline \multicolumn{1}{|c|}{ Alternatif } & \multicolumn{1}{c|}{ Nilai V } \\
\hline A1 & 3.28 \\
\hline A2 & 3.28 \\
\hline A3 & 2.12 \\
\hline A4 & 2.44 \\
\hline A5 & 2.40 \\
\hline A6 & 3.28 \\
\hline A7 & 4.20 \\
\hline
\end{tabular}

Sehingga diperoleh urutan perangkingan dari yang terbesar hingga terkecil adalah dapat dilihat pada Tabel 8 .

Tabel 8. Urutan Perangkingan

\begin{tabular}{|l|c|c|}
\hline \multicolumn{1}{|c|}{ Alternatif } & Nilai V & Rangking \\
\hline A7 = Saka Waradhana & 4.20 & 1 \\
\hline A1 = Rina Vitasari & 3.28 & 2 \\
\hline A2 = Intan Yulia & 3.28 & 3 \\
\hline $\begin{array}{l}\text { A6 = Andi } \\
\text { Normansyah }\end{array}$ & 3.28 & 4 \\
\hline A4 = Tito Safe'i & 2.44 & 5 \\
\hline A5 = Diego Armandito & 2.40 & 6 \\
\hline A3 = Annisa & 2.12 & 7 \\
\hline
\end{tabular}


Berdasarkan hasil perangkingan, maka nilai tertinggi diperoleh oleh A7 ( Saka Waradhana) dengan nilai 4.20. sehingga A7 adalah alternatif terbaik.

\section{E. Validasi Hasil}

Validasi hasil adalah proses untuk menentukan tingkat validitas sistem. Pengujian validitas perhitungan program dilakukan dengan membandingkan hasil perhitungan sistem yang menggunakan metode Simple Additive Weighting (SAW) dengan hasil perhitungan pihak HRD. Selanjutnya dalam pengujian ini akan dicari tingkat kinerja sistem dengan menggunakan beberapa inputan data yang diambil dari data penilaian karyawan kontrak. Hasil pengujian dapat dilihat pada data berikut. Gambar 17 grafik absensi karyawan Indoluxe dalam sebulan.

Gambar 17. Grafik Absensi Karyawan Indoluxe dalam sebulan.

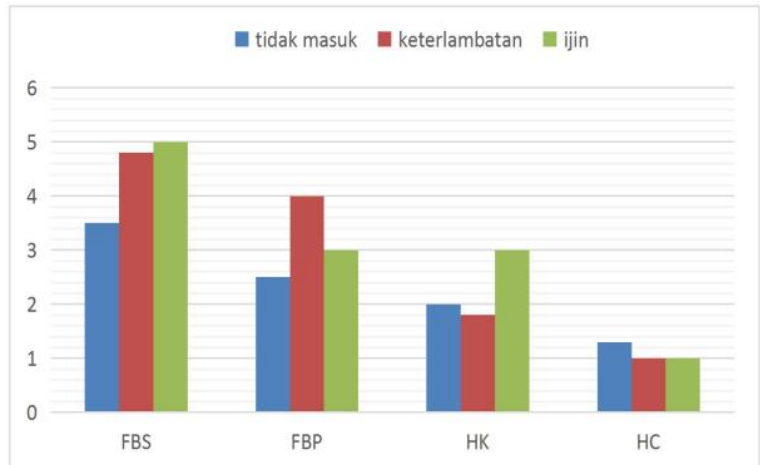

Keterangan:

1. FBS : Depertemen Food \& Beverage Servise

2. FBP : Departemen Food \& Beverage Product/Kitchen

3. HK : Departemen House Keeping

4. HC : Departemen Human Capital

Dari data grafik absen, diperoleh bahwa departemen FBS menduduki peringkat pertama tingkat keterlambatan. Karena dari pihak HRD akan menilai absensi karyawan dalam menentukan kontrak kerja. Jika dalam sebulan diketahui keterlambatannya lebih dari 20 kali, maka pihak hotel berhak memberhentikan kontrak kerja karyawan tersebut tanpa harus one month notie, dapat dilihatpada tabel dibawah ini.

Tabel 9.Data Absensi Karyawan Kontrak Indoluxe Hotel Jogjakarta

\begin{tabular}{|c|l|c|c|c|l|}
\hline \multirow{2}{*}{ No } & \multirow{2}{*}{$\begin{array}{c}\text { Nama Karyawan } \\
\text { Kontrak }\end{array}$} & \multicolumn{2}{|c|}{$\begin{array}{c}\text { Data Absensi/ } \\
\text { bulan }\end{array}$} & \multirow{2}{*}{ Rangking } & Keterangan \\
\cline { 3 - 4 } & & Absensi & \multicolumn{1}{|c|}{ Nilai } & & \\
\hline 1 & Rafenska Ferdinal & 0 & $4.00-4.30$ & 1 & SM \\
\hline 2 & Vinda & 0 & $4.00-4.30$ & 1 & HC \\
\hline 3 & Andi Normansyah & 5 & $3.30-4.00$ & 4 & FBS \\
\hline 4 & Ben Soebekti & 4 & $3.30-4.00$ & 2 & HK \\
\hline 5 & Saka Wardhana & 0 & $4.00-4.30$ & 1 & FBS \\
\hline 6 & Laras Anjani & 8 & $2.25-2.40$ & 8 & HC \\
\hline 7 & Maryono & 10 & $1.50-2.00$ & 10 & FBP \\
\hline 8 & Christine & 11 & $1.30-1.50$ & 11 & HK \\
\hline
\end{tabular}

\begin{tabular}{|c|l|c|c|c|l|}
\hline \multirow{2}{*}{ No } & \multirow{2}{*}{$\begin{array}{c}\text { Nama Karyawan } \\
\text { Kontrak }\end{array}$} & \multicolumn{2}{|c|}{$\begin{array}{c}\text { Data Absensi/ } \\
\text { bulan }\end{array}$} & \multirow{2}{*}{ Rangking } & Keterangan \\
\cline { 3 - 5 } & & Absensi & Nilai & & \\
\hline 9 & Nana Giyana & 7 & $2.40-2.44$ & 5 & FO \\
\hline 10 & Rina Vitasari & 2 & $3.30-4.00$ & 2 & FBS \\
\hline 11 & Intan Yulia & 3 & $2.45-3.30$ & 3 & FBS \\
\hline 12 & Tito Safe'i & 7 & $2.40-2.44$ & 5 & FBS \\
\hline 13 & Reynald Josua & 12 & $1.50-2.00$ & 10 & HK \\
\hline 14 & Diego Armandito & 8 & $2.25-2.40$ & 6 & FBS \\
\hline 15 & Anisa & 9 & $2.00-2.25$ & 7 & FBS \\
\hline
\end{tabular}

Selanjutnya dalam pengujian hasil, dilakukan dengan membandingkan hasil perhitungan sistem yang menggunakan metode Simple Additive Weighting (SAW) dengan hasil perhitungan pihak HRD. Tabel 10.

Tabel 10. Validasi Hasil

\begin{tabular}{|c|c|c|c|c|c|}
\hline \multirow{2}{*}{ No } & \multirow{2}{*}{$\begin{array}{c}\text { Nama Karyawan } \\
\text { kontrak }\end{array}$} & \multicolumn{2}{|c|}{ Metode SAW } & \multirow{2}{*}{$\begin{array}{c}\begin{array}{c}\text { Indoluxe } \\
\text { Hotel }\end{array} \\
\text { Rangking }\end{array}$} & \multirow{2}{*}{ Keterangan } \\
\hline & & $\begin{array}{c}\text { Nilai } \\
\mathrm{V}\end{array}$ & Rangking & & \\
\hline 1 & $\begin{array}{l}\text { Saka } \\
\text { Waradhana }\end{array}$ & 4.20 & 1 & 1 & Sesuai \\
\hline 2 & Rina Vitasari & 3.28 & 2 & 2 & Sesuai \\
\hline 3 & Intan Yulia & 3.28 & 3 & 3 & Sesuai \\
\hline 4 & $\begin{array}{l}\text { Andi } \\
\text { Normansyah }\end{array}$ & 3.28 & 4 & 4 & Sesuai \\
\hline 5 & Tito Safe'i & 2.44 & 5 & 5 & Sesuai \\
\hline 6 & $\begin{array}{l}\text { Diego } \\
\text { Armandito }\end{array}$ & 2.40 & 6 & 6 & Sesuai \\
\hline 7 & Annisa & 2.12 & 7 & 7 & Sesuai \\
\hline
\end{tabular}

Berdasarkan hasil yang ditunjukkan Tabel 10 maka persentasi kinerja dihitung sebagai berikut :

$$
\begin{aligned}
\text { Tingkat kinerja sistem } & =\text { (jumlah data sesuai/jumlah } \\
& \text { data)*100\% } \\
= & (7 / 7) * 100 \% \\
= & 100 \%
\end{aligned}
$$

\section{KESIMPULAN}

Setelah dilakukan penelitian, maka dapat diperoleh kesimpulan bahwa :

1. Implementasi sistem pendukung keputusan perpanjangan karyawan kontrak menggunakan metode Simple Additive Weighting berhasil memberikan urutan nilai tertinggi dari daftar karyawan kontrak yang telah bekerja dan akan dijadikan pedoman oleh pihak HRD dalam menentukan pegawai yang akan diterima.

2. Berdasarkan pada perbandingan antara hasil metode Simple Additive Weighting dan hasil Indoluxe Hotel, 7 data responden yang diteliti terdapat 7 orang yang sesuai maka dapat diperoleh kinerja hasil sistem sebesar $100 \%$ (seratus persen). 
3. Dengan adanya sistem yang dibuat ini dapat menentukan keputusan perpanjangan kontrak karyawan yang sesuai prosedur perusahaan.

\section{DAFTAR PUSTAKA}

[1] B. Rianto, "Sistem Pendukung Keputusan Penerimaan Karyawan Menggunakan Metode Analytical Hierarchy Process ( AHP ) Studi Kasus: RB . Nilam Sari Tembilahan," Sist. Pendukung Keputusan Penerimaan Karyawan Menggunakan Metod. Anal. Hierarchy Process ( AHP ) Stud. Kasus RB. Nilam Sari Tembilahan, vol. 2, no. 2, pp. 29-38, 2016.

[2] W. S. Widani, I. P. Ningrum, and R. Ramadhan, "Sistem pendukung keputusan penerimaan karyawan pada pt. sultra inti roda perkasa menggunakan metode," vol. 2, no. 1, pp. 129-140, 2016.

[3] O. Fajarianto, A. S. Widodo, M. Iqbal Hanafri, Arianto, and A. Muchlisin Fauzi, "Sistem Pendukung Keputusan Untuk Penerimaan Calon Karyawan Outsourcing Dengan Metode Simple Additive Weighting (SAW)," J. Sains dan Inform., vol. 4, no. 1, pp. 29-39, 2018, doi: 10.22216/jsi.v4i1.2778.

[4] A. Rikki, Murni Marbun, and Jonson R. Siregar, "Sistem Pendukung Keputusan Penerimaan Karyawan Dengan Metode SAW Pada PT. Karya Sahata Medan," J. Informatics Pelita Nusant., vol. 1, no. 1, pp. 38-46, 2016, doi: 10.1111/14710528.13220.

[5] N. C. Resti, "Penerapan Metode Simple Additive Weighting (SAW) pada Sistem Pendukung Keputusan Pemilihan Lokasi untuk Cabang Baru Toko Pakan UD. Indo Multi Fish,” Intensif, vol. 1, no. 2, p. 102, 2017, doi: 10.29407/intensif.v1i2.839.

[6] F. Agustini, "Metode Simple Additive Weighting Dalam Penilaian Guru Pns Berprestasi," JST (Jurnal Sains dan Teknol., vol. 8, no. 2, 2019, doi: 10.23887/jst-undiksha.v8i2.20986.

[7] N. Norman, R. Rosida, S. Putri, and N. Nurahman, "Penggunaan Sistem Pendukung Keputusan Seleksi Atlet Silat Sekotawaringin Timur Menggunakan Metode Simple Additive Weighting," J. Sist. Komput. dan Inform., vol. 1, no. 2, p. 134, 2020, doi: 10.30865/json.v1i2.1978.

[8] M. A. Fadlun, K. Arivanty, H. W. S, and R. Amalia, "Sistem Pendukung Keputusan Untuk Menentukan Penerima Beasiswa Bank BRI Menggunakan FMADM (Studi Kasus: Mahasiswa Fakultas Teknologi Industri Universitas Islam Indonesia)," Semin. Nas. Apl. Teknol. Inf., vol. 2009, no. Snati, pp. 62-67, 2009.

[9] S. H. P. Kusumadewi, Aplikasi Logika Fuzzy Untuk Pendukung Keputusan, Yogyakarta: Graha Ilmu, 2010.
[10] Kadir, Pengenalan sistem informasi, Yogyakarta: Andi, 2003. 